\title{
An Evaluation of Extension Programs to Enhance Water Quality through Nutrient Management in the Urban Landscape \\ P. Diane Relf ${ }^{1}$ and

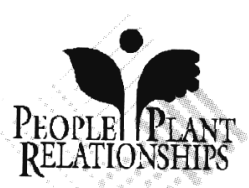

David McKissack ${ }^{2}$

Additional index words. Master Gardeners, runoff, Chesapeake Bay, fertilizer, nonpoint source pollution

Summary. A mass media water-quality program aimed at changing lawn and garden fertilization practices of homeowners successfully elicited responses from individuals by using local cooperative extension offices and newsletters. Traditional extension media tools, such as radio and news releases, were less successful in eliciting requests for further information. In addition, the program reached more people by transmitting the information in the form of a calendar than it reached in the first year through videotapes and slide sets created for use in public and Master Gardener training.

$\mathrm{D}$ uring the last decade, nonpoint source pollution has damaged the quality of water in the Chesapeake Bay, its tributaries and estuaries, and the groundwater of the states surrounding it (U.S. Environmental Protection Agency, 1983). There are $>20$ state and private agencies conducting programs to address this problem and reduce $\mathrm{N}$ and P loading in the Chesapeake Bay $40 \%$ by the year 2000 . One type of nonpoint source pollution responsible for this damage is nutrient runoff attributable to improper fertilization by urban and suburban residents. To help alleviate this problem, the Virginia Tech Office of Consumer Horticulture $(\mathrm{OCH})$, through a grant from the Virginia Dept. of Conservation and Historic Resources, Division of Soil and Water Conservation (DSWC), developed the Nutrient Management Education Program (NMEP) to educate the public on the proper selection and application of fertilizers and the connection between nutrient runoff and water quality.

As part of the NMEP, the OCH developed a nutrientmanagement calendar and training resources including audiovisual materials and cooperative extension publications. The NMEP consisted of two parts: 1) training extension Master Gardeners so they in turn could present programs in their local areas and 2) conducting a statewide, mass media,

${ }^{1}$ Associate Professor of Horticulture and Extension Specialist for Consumer Horticul ture.

${ }^{2}$ Program Support Technician Senior. Dept. of Horticulture.

Virginia Polytechnic Institute and State University, Blacksburg, VA 24061. 
nutrient-management educational effort including the distribution of the calendar. Because of the number ofagencies involved in the effort to improve the quality of the Chesapeake Bay, it is not possible to quantify the impact of a specific educational program on the water quality. However, data were collected to make a comparison between two educational approaches in terms of their cost-effectiveness in reaching and motivating audiences. The number of requests for copies of the calendar was used to evaluate the potential effectiveness of the mass media educational program in changing citizen behavior as indicated by their taking the independent action of writing to request information. Data were collected to compare the cost of the calendar per person reached with the cost of training Master Gardeners per person they reached with the educational program.

\section{The Nutrient Management Education Program}

In order to transmit its educational message to the public, NMEP used two established cooperative extension programs. One of these programs was the Virginia Gardener Program, a mass-media effort developed and administered by the OCH. The NMEP was incorporated into the weekly radio program, monthly newsletter, weekly newspaper columns, cooperative extension publications, and computer directory used by cooperative extension agents in developing local radio programs, newsletters, and newspaper articles (Ralf et al., 1991). Another program used by NMEP was the Virginia Master Gardener Program, which has >1200 trained volunteers conducting horticultural education programs in 40 of the 107 cooperative extension units in the state.

To provide information for the distribution network, the $\mathrm{OCH}$ developed nutrient management educational resources including videotapes, slide sets, cooperative extension publications, and a calendar (see sidebar). The videotapes, slide sets, and publications were used to train Master Gardeners, who then used the materials to conduct water-quality and nutrient-management programs in their communities.

The mass-media educational program used the Virginia Gardener information network of radio, newspaper, and newsletters to reach the general public. Radio programs consisted of interviews with cooperative extension specialists who discussed how their area of expertise (landscaping, soil fertility, turfgrass management, etc.) related to nutrient management and water quality. These interviews were broadcasted on 58 radio stations with an estimated weekly audience of 1 million persons. In addition, articles concerning good nutrient-management practices in home gardens (soil testing, cover-cropping, irrigation, etc.) were made available to 110 newspapers. Similar articles also were placed in two statewide newsletters (circulation totaling 6584) aimed at Master Gardeners, home gardeners, and amateur horticulturists.

A 15-month nutrient-management calendar was designed to provide concise explanations of cultural practices and their positive effects on water quality (see Table 1 for list of topics). This calendar had two specific functions: 1) to provide a tool for assessing the response of individuals to various mass-media programs and 2) to educate the recipients of the calendar regarding effective water-quality practices in

\section{Nutrient Management Education Program Resources}

\section{Videotapes:}

"Proper Management of Fertilizers in Home Vegetable Gardens" (6 min). Explains the role ofchemical and organic fertilizers in plant growth and their impact on pollution. Recommends amount and best time for fertilizer application.

"Proper Management of Fertilizers on Home Lawns" (8 min). Explains nutrient requirements of cool- and warm-season grasses. Suggests methods for determining optimum amounts of fertilizer for lawn growth and prevention of pollution.

\section{Slide Sets:}

"Proper Management of Fertilizers in Home Vegetable Gardens" (40 slides). Examines chemical and organic fertilizers, their nutrient composition, soil testing, and the timing and application of fertilizes to vegetables.

"Proper Management of Fertilizers on Home Lawns" (40 slides). Discusses lawn fertilizer nutrient content, cool- and warm-season grasses, and methods of determining optimum amounts of fertilizer.

"Calibrating Your Lawn Spreader" (32 slides). Describes types of fertilizer spreaders. Explains methods of determining optimum amounts of fertilizer and procedures for calibrating spreaders.

\section{Printed Materials:}

Groundwater Quality and the Use of Lawn and Garden Chemicals by Homeowners. Virginia Coop. Ext. Serv. Publ. 426-059.

1989 Nutrient Management Calendar. Virginia Coop. Ext. Serv. Publ. 426-612.

Calibrating Your Spreader. Virginia Coop. Ext. Serv. Publ. 430-017.

Table 1. Topics addressed in the 15-month nutrient calendar.

\begin{tabular}{lll}
\hline Year & Month & \multicolumn{1}{c}{ Topic } \\
\hline 1989 & January & Understanding fertilizers \\
& February & Erosian control \\
March & Enhancing lawn health \\
April & Tilling the soil \\
May & Fertilizing the vegetable garden \\
& June & Irrigation \\
& July & Reducing the effects of drought \\
August & Improving soil \\
& September & Protecting soil in the winter \\
& October & Testing soil \\
& November & Uses for leaves \\
& December & Winterizing trees and shrubs \\
& & \\
& January & Soil composition \\
& February & Plant nutrition \\
& March & Meadow and wildflower plantings
\end{tabular}


a format that allowed for repeated exposure over the course of a year.

To assess response to mass-media programs, the calendar was offered free on the Virginia Gardener radio program, in newspaper columns, in newsletters, and by agents in the 107 Virginia cooperative extension offices. To receive the calendar, individuals wrote directly to Virginia Tech. A separate code was used as part of the address given by each mass-media outlet and each cooperative extension office, making it possible to identify which source generated the request.

\section{Results}

Within 2 months of beginning its mass-media program, the $\mathrm{OCH}$ received 14,000 requests for garden calendars. Tabulation of requests and shipping of calendars were handled by the Virginia Tech Extension Distribution Center. Distribution of the calendars based on the source that generated the request is shown in Table 2 .

In the first 3 months of implementing the NMEP, the $\mathrm{OCH}$ staff and cooperative extension agents trained 240 Master Gardeners. Master Gardeners in turn used their knowledge to conduct nutrient management educational programs for other individuals and civic groups. Over the ensuing 6 months, they reached 1295 citizens.

The relative costs of these two approaches beyond normal ongoing program costs are compared in Table 3.

The relatively small number of calendar orders attributable to radio and newspapers indicates that these media were inadequate to elicit a response requiring action from the target audience. The cooperative extension service traditionally has viewed radio and news releases as providing inexpensive access to large audiences. However, the limited action elicited as compared to audience size indicates that the access is primarily in the form of awareness rather than the behavioral change of taking the action to gain more information.

The requests for calendars through the newsletters and cooperative extension offices, however, indicated that the

Table 2. Distribution of calendar requests through media source.

\begin{tabular}{lc}
\hline Media source & No. of calendars ordered \\
\hline Radio & 47 \\
Press releases & 3,818 \\
Newsletters & 1,209 \\
Extension offices & 6,840 \\
Miscellaneous $^{z}$ & $\underline{2,086}$ \\
Total & 14,000
\end{tabular}

${ }^{\text {zTalksgiven by extension specialists, on-campusstudent and staffrequests, and }}$ unknown sources of referral (i.e., word-of-mouth).
Table 3. Costs of nutrient management educational program.

\begin{tabular}{|c|c|}
\hline Overhead & Cost \\
\hline \multicolumn{2}{|c|}{ Calendar } \\
\hline Staff & $\$ 8,500$ \\
\hline Printing & $\$ 7,000$ \\
\hline Mailing & $\$ 1,800$ \\
\hline Calendar total & $\$ 17,300$ \\
\hline \multicolumn{2}{|c|}{ Master Gardener } \\
\hline Staff & $\$ 3,000$ \\
\hline Video and slide production & $\$ 7,326$ \\
\hline Training (staff and traval) & $\$ 7,790$ \\
\hline Master Gardener total & $\$ 18,116$ \\
\hline Total cost & $\overline{\$ 35,416}$ \\
\hline
\end{tabular}

more directed the announcement, the greater the request rate for the information. Addressed to a well-defined audience of Master Gardeners or paid subscribers, newsletters had a response rate of $18 \%$, indicating that newsletters are an effective tool for eliciting action. Although the local cooperative extension agents generated the largest number of requests for calendars (6840), this total represents the efforts of 107 agents, and thus, a large investment of extension resources.

Compared to the mass-media efforts, the training of Master Gardeners reached a relatively small audience during the first 6 months of the program. In terms of cost per citizen reached, the calendar was more effective than the Master Gardener training (see Table 3), with a $\$ 17,300$ investment reaching 14,000 individuals. The videotapes and slide sets used to teach 240 Master Gardeners reached only 1295 citizens at a cost of $\$ 18,116$. However, this may be the most effective way to permanently place water-quality knowledge in a community, since the training is individualized and the audiovisual resources will be used to train and support Master Gardener programs for many years. These experiences can be used to 1) design an educational approach suited to the goals of the particular program and/or 2) solicit to immediate action a long-term and geometrically increasing knowledge base in the community.

\section{Literature Cited}

U.S. Environmental Protection Agency, 1983. Chesapeake Bay: A framework for action. U.S. Environ. Protection Agency, Washington, D.C.

Relf, D., E. Silva, and V.K. Nathan. 1992. A consumer horticulture computer network for extension agents. HortTechnology 2(2):251-253. 